\title{
Dehydrogenase enzyme cytochemistry of unfixed leucocytes
}

\author{
JOHN STUART AND JENNIFER S. SIMPSON \\ From the Department of Haematology, The Children's Hospital, Birmingham
}

SYNOPSIS An inert, synthetic, sucrose polymer (Ficoll) has been found to have a protective $\vec{c}$ effect on leucocytes during incubation for cytochemical reactions at $37^{\circ} \mathrm{C}$. This permits enzyme $\frac{\mathbb{D}}{\circ}$ cytochemistry to be performed on unfixed bone marrow and peripheral blood smears, and on $\frac{\mathbb{D}}{3}$ leucocytes cultured in vitro, thus avoiding enzyme inhibition by the use of a fixative. The technique is suitable for the demonstration of both cytoplasmic and intramitochondrial dehydrogenase enzyme activity.

A monolayer of bone marrow cells spread on to a glass slide provides a unique system for the study of enzyme activity within individual cells. The trauma to tissue, with potential loss of enzyme activity, which is an intrinsic disadvantage of tissue sections and homogenates, is avoided; the enzyme activity of normal cells at different stages of maturation and under varying degrees of benign hyperplasia can be studied; and both normal and leukaemic cells can be readily identified and their enzyme activities compared.

While the advantages of this system are considerable, in particular for the study of enzyme activity in leukaemic blast cells, it is technically difficult to retain the cells on the slide when it is subsequently immersed in an incubation solution at $37^{\circ} \mathrm{C}$. When no fixative is used, partial or complete cellular disruption usually results with loss of a variable amount of soluble enzymes into the incubation solution, and there is difficulty also in recognizing those damaged cells which remain on the slide. The use of a fixative, while retaining the cells on the slide, renders cell membranes highly permeable and inhibits a variable amount of enzyme activity.

We have found that the addition to the incubation solution of a synthetic, high-molecular weight, inert, sucrose polymer allows unfixed smeared cells to be retained on glass slides throughout prolonged incubation at $37^{\circ} \mathrm{C}$. The technique has been found suitable for the Received for publication 9 February 1970. demonstration of glycolytic and respiratory pathway dehydrogenases, both cytoplasmic and intramitochondrial in localization, in bone marrow and $\Phi$ peripheral blood leucocytes, and in cells cultured in vitro.

\section{Method}

Fairly dilute bone marrow or buffy-coat peri- $\frac{3}{3}$ pheral blood films are allowed to air dry at room $ᄋ$ temperature for approximately 60 minutes. $A$ Perspex ring $(1.5 \times 0.5 \mathrm{~cm})$ is attached by a thin $ᄋ$ film of paraffin wax to the area just proximal to $\supset$ the tail of the film and filled with freshly prepared incubation medium made up as follows:

Buffer, glycylglycine.........0.05M, $p \mathrm{H} 7 \cdot 6^{\circ}$ Tetrazolium salt, nitroblue tetrazolium (Sigma), ్ㅗㅇ .................... $\mathrm{mg} / \mathrm{ml}$ buffer ${ }^{\omega}$ Calcium salt, $\mathrm{CaCl}_{2} \cdot 2 \mathrm{H}_{2} \mathrm{O} \ldots \ldots 13 \mathrm{mg} / \mathrm{ml}$ buffer Inert polymer, Ficoll (Pharmacia).......... $\ldots \ldots \ldots \ldots \ldots \ldots \ldots \ldots \ldots 400 \mathrm{mg} / \mathrm{ml}$ buffer $\varnothing_{\mathscr{C}}$ Coenzyme, NAD ${ }^{1}$ or NADP ${ }^{2}$ (Boehringer), .... ..................... $\mathrm{mg} / \mathrm{ml}$ buffer Substrate................. 0.05-0.1M $(0.005 \mathrm{M}$ for enzymes of the pentose phosphate shunt)

The final $p \mathrm{H}$ is $7 \cdot 3$ and incubation is carried out

${ }^{1}$ Nicotinamide adenine dinucleotide, acid free.

${ }^{2}$ Nicotinamide adenine dinucleotide phosphate, disodium salt. 
in an atmosphere of nitrogen in a $37^{\circ} \mathrm{C}$ humidityincubation box (Chayen, Bitensky, Butcher, and Poulter, 1969). When incubation is complete the ring is removed, the incubation solution tipped off, and the reaction terminated by fixing the film in $40 \%$ formalin for 10 minutes.

During incubation, the tetrazolium salt is reduced to a dark-coloured, insoluble formazan which is deposited within each cell in proportion to dehydrogenase enzyme activity. In these experiments the cell nuclei were counterstained for 10 minutes with $2 \%$ aqueous methyl green and the amount of formazan produced was assessed by means of a scanning and integrating microdensitometer (Barr and Stroud, type GN 2) set at the wavelength of green light $(550 \mathrm{~nm})$.

\section{Results}

OPTIMAL CONCENTRATION OF FICOLL

A number of additives of varying molecular weight were found to have a protective effect against cellular disruption (Table I). The concentrations used varied between 5 and $40 \% \mathrm{w} / \mathrm{v}$; in general a higher concentration was required for incubation periods greater than 60 minutes, but some of the solutions then become too viscous for ease of handling. A $40 \%$ concentration of Ficoll was found to give good cellular preservation, minimal $p \mathrm{H}$ drop when added to the incubation solution, a clear background between cells with no crystalline deposit, and a working solution of low viscosity at room temperature. Several minutes' stirring was required to ensure solution and the mixture then had to stand for approximately $\mathbf{1 0}$ minutes to allow bubbles to disperse.

\begin{tabular}{|c|c|c|}
\hline Chemical & $\begin{array}{l}\text { Approximate } \\
\text { Molecular } \\
\text { Weight }\end{array}$ & Source \\
\hline \multicolumn{3}{|c|}{ Polyvinyl alcohol (Polyviol) } \\
\hline $\begin{array}{l}\text { V } 03 / 140 \\
\text { W } 25 / 150 \\
\text { W } 40 / 140\end{array}$ & $\begin{array}{r}15,000 \\
80,000 \\
100,000\end{array}$ & $\begin{array}{l}\text { Bush, Beach and Segner Bayley Ltd, } \\
175 \text { Tottenham Court Road, } \\
\text { London W1P 08J }\end{array}$ \\
\hline \multicolumn{3}{|c|}{ Collagen polypeptide } \\
\hline $\begin{array}{l}5176 \\
5177 \\
5178\end{array}$ & $\begin{array}{l}15,000 \\
18,000 \\
21,000\end{array}$ & $\begin{array}{l}\text { Endeavour Chemical Co. Ltd, } \\
\text { Beach Road, } \\
\text { Newhaven, Sussex }\end{array}$ \\
\hline Ficoll & 400,000 & $\begin{array}{l}\text { Pharmacia (G.B.) Ltd, } \\
75 \text { Uxbridge Road, } \\
\text { London, W5 }\end{array}$ \\
\hline
\end{tabular}

Table I Additives enhancing the preservation of smeared marrow cells

OPTIMAL SUBSTRATE, TETRAZOLIUM SALT, AND COENZYME CONCENTRATIONS

For an incubation period of 60 to 180 minutes a concentration of $1 \mathrm{mg} / \mathrm{ml}$ buffer was found to be optimal for nitroblue tetrazolium and for each of the two coenzymes used. Optimal substrate concentrations for lactate, $\alpha$-glycerophosphate, succinate, malate, and glutamate dehydrogenasts fell in the range 0.05 to $0.1 \mathrm{M}$, but for enzymes $\underline{\mathrm{of}}$ the pentose phosphate shunt no increase in enzyme activity was achieved above a substrale concentration of $0.005 \mathrm{M}$. Optimal substrate copcentrations were similar for both normal and leukaemic cells, and in neither instance coup enzyme inhibition be induced by five-fold increass in substrate concentration.

\section{INCUBATION PERIOD}

Linear activity-time curves were obtained when formazan production was measured at 60,1200 , and 180 minutes (Fig. 1) but for most purposes

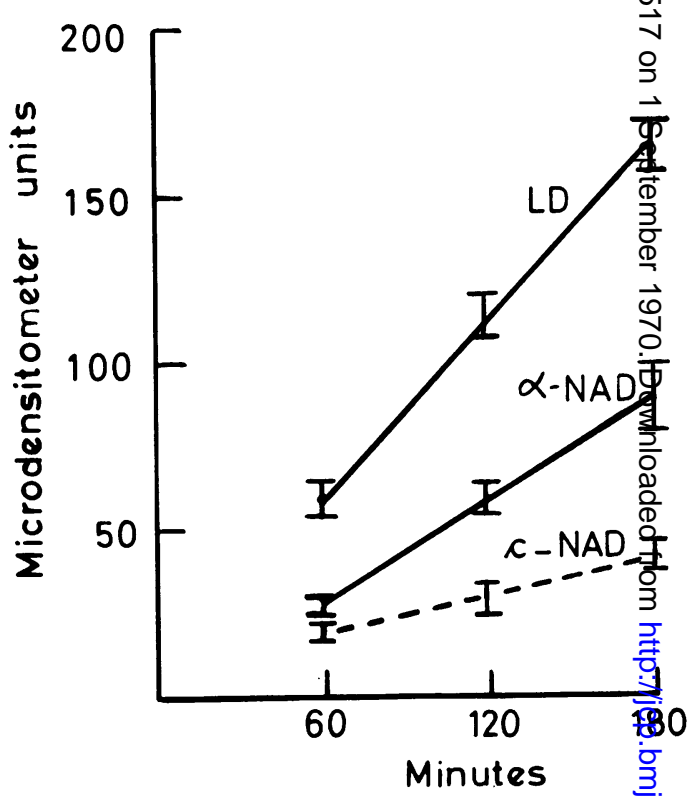

Fig. 1 Activity-time curves for lactate $(L D)$ and $\alpha-$ glycerophosphate NAD-dependent $(\alpha-N A D)$ dehydrogenases, together with control activity in theo absence of substrate but with added coenzyme $(c-N A D)$.

Activity is represented by arbitrary microdensito- 을. meter units at an absorption setting of 20 , extinctioß value of 1.0 , and wavelength of $550 \mathrm{nn}$. Each point represents the mean scores for 50 cells \pm 1 standard deviation.

an incubation period of 90 minutes is reco离mended. Beyond this time, formazan production may become so heavy as to obscure morplological recognition of cells. Prolonged incubation periods of the order of 16 hours (Melnick, 19\%) were not found necessary, and are also not thought to be desirable since substrate or cofactor exhaustion may become a limiting factor in cells which have an initial high enzyme activity. 


\section{COMPARISON WITH FIXED FILMS}

The formazan production in unfixed marrow cells protected by a $40 \%$ concentration of Ficoll was consistently greater than that obtained in cells fixed in $60 \%$ acetone at room temperature (Quaglino and Hayhoe, 1960), 100\% acetone at $4{ }^{\circ} \mathrm{C}$ (Melnick, 1968), and $100 \%$ ethanol at $-70^{\circ} \mathrm{C}$ (Stuart and Skowron, 1968). This was particularly noticeable for dehydrogenases with weak activity, eg, glucose-6-phosphate dehydrogenase. Preservation of the unfixed films was not significantly inferior except for a variable loss of erythrocytes, but this confers an advantage when using the microdensitometer in that blank background readings can be taken adjacent to each cell.

Acetone fixation of films before immersion in an incubation solution containing $40 \%$ Ficoll did not increase formazan deposition compared with unfixed films processed simultaneously. Therefore any beneficial effect of acetone fixation, by virtue of a lipid-clearing effect or by increasing membrane permeability, was more than counteracted by its inhibitory effect on enzyme activity. Refrigeration of unfixed films at $-20^{\circ} \mathrm{C}$ for 60 minutes before incubation increases membrane permeability and this technique has been used to enhance the cytochemical demonstration of lysosomal enzyme activity (Lorbacher, Yam, and Mitus, 1967). It was not found possible to enhance either extramitochondrial (lactate and glucose-6-phosphate) or intramitochondrial (succinate) dehydrogenase $\stackrel{\rho}{\overline{7}}$ activity by this means, and it is presumed that the damage to cytoplasmic membranes in smeared cells is sufficient in itself to allow relatively free $\vec{\partial}$ passage of soluble chemicals of relatively low molecular weight.

CONTROL FILMS

Control films lacking substrate and coenzyme (c) $\overparen{\otimes}$ and lacking substrate but including the appro- 0 priate coenzyme (c-NAD: c-NADP) were included ${ }^{\infty}$ with each marrow specimen studied. Both $\mathrm{c}$ and $\vec{O}$ c-NADP invariably showed no formazan produc- $\vec{\overrightarrow{ }}$ tion or only an occasional formazan granule, $\stackrel{\omega}{\omega}$ while c-NAD usually showed more definite, but weak, diffuse positivity (Fig. 1). This is probably due to the action of the dehydrogenase, together $\omega$ with added coenzyme, on a small amount of $\sigma$ endogenous substrate (mainly lactate) retained within the cell, and the value for c-NAD therefore 0 requires to be subtracted from the gross values? obtained for the NAD-dependent dehydrogenases $c)$ (lactate, glutamate, malate, and $\alpha$-glycero- $\frac{\mathbb{O}}{0}$ phosphate).

Attempts were made to dialyse out retained $\frac{7}{\sigma}$ substrate by immersion of unfixed films in normal $\stackrel{\Phi}{-}$ saline, glycylglycine buffer $(0.05 \mathrm{M}, p \mathrm{H} 7.6)$, and $\overrightarrow{0}$ pyrophosphate buffer $(0.005-0.015 \mathrm{M}, p \mathrm{H}$ 7.6) ఫ (Wagner, Meyerriecks, and Sparaco, 1956) for

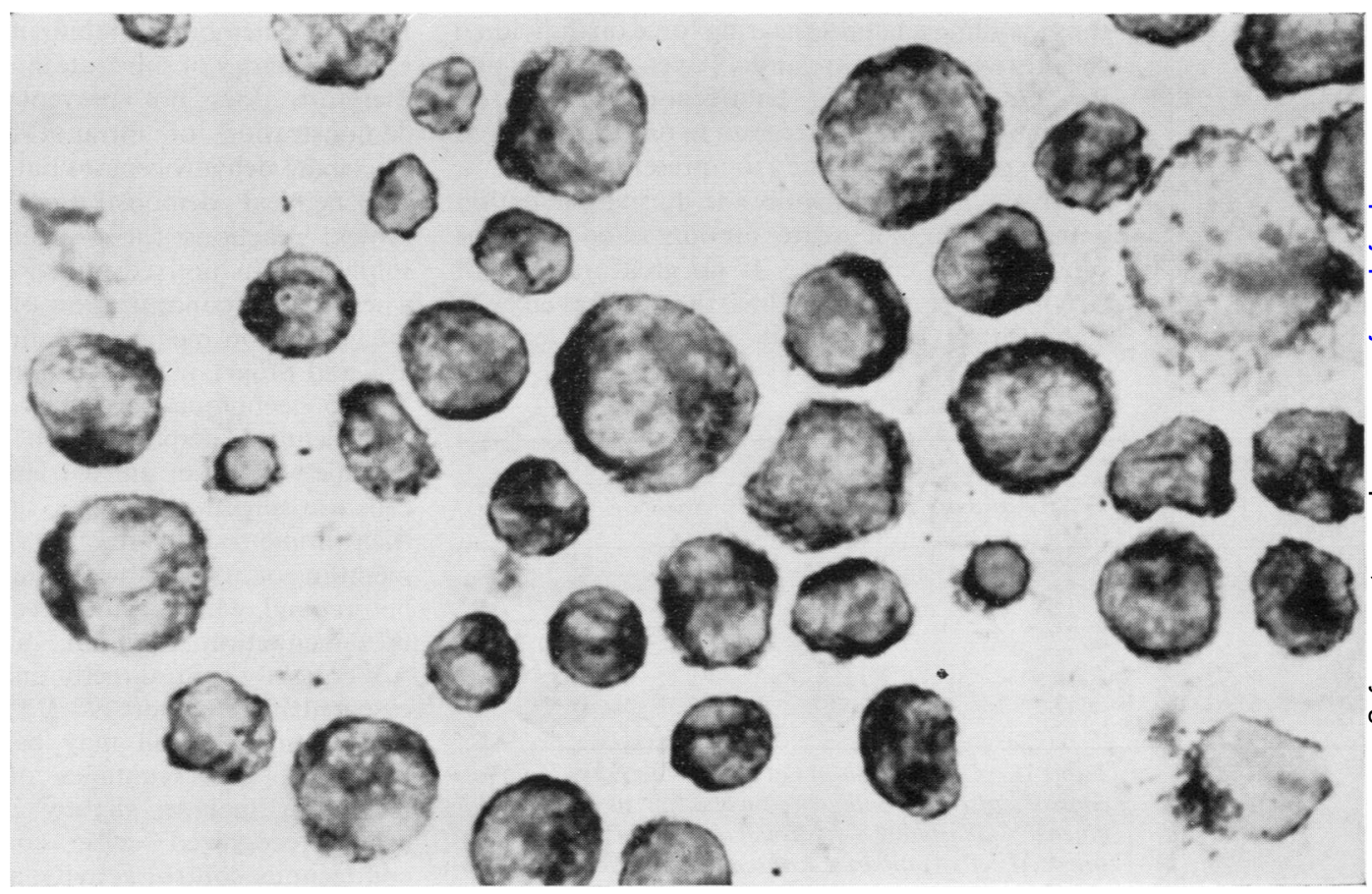

Fig. 2 Lactate dehydrogenase activity in unfixed smeared lymphoblasts after incubation for 90 minutes in appropriate incubation solution with added Ficoll $(40 \% \mathrm{w} / \mathrm{v})$. No nuclear counterstain. 
periods of five to 60 minutes. Partial or complete cell lysis occurred unless Ficoll was incorporated in the aqueous solution. In the presence of Ficoll no selective removal of endogenous substrate was achieved: either no reduction in formazan deposition was achieved or equal reduction of formazan production occurred in the presence and absence of added exogenous substrate. Similar results were obtained when intact marrow cells were suspended in the same solutions for 18 hours at $4{ }^{\circ} \mathrm{C}$ and then spun on to glass slides in a cytocentrifuge before immersion in the appropriate incubation solution.

\section{RETENTION OF ENZYME ACTIVITY}

The lateral shearing force required to convert the normally globular-shaped marrow cell into its familiar flattened form causes partial cytoplasmic membrane disruption. If the cell is then immersed in an aqueous incubation solution this is sufficient to cause loss by diffusion of intracellular substrate to give near negative control preparations. In order to test for loss of enzyme activity by the same mechanism, the unfixed marrow film technique, using $40 \%$ Ficoll, was performed in parallel with a second method in which 1 drop of marrow was added to $1.0 \mathrm{ml}$ of incubation solution, also containing $40 \%$ Ficoll, in a test tube. Following incubation for 90 minutes at $37^{\circ} \mathrm{C}$, the latter cells are washed once in $5 \%$ glucose and spun directly onto glass slides in a cytocentrifuge, thus avoiding a lateral shearing force on individual cells (Stuart, Bitensky, and Chayen, 1969). Using the latter technique, endogenous or control enzyme activity is greater than in unfixed, smeared films, presumably due to preservation of a relatively intact cell membrane during incubation with retention of a greater amount of endogenous substrate and coenzyme. If no great amount of enzyme is lost in spread films, then the net enzyme activity (test less control) should be at least as

\begin{tabular}{|c|c|c|c|c|c|}
\hline \multicolumn{3}{|c|}{ Smeared Cells } & \multicolumn{3}{|c|}{ Cells in Suspension } \\
\hline $\begin{array}{l}\text { G-6-PD } \\
\text { (Gross) }\end{array}$ & $c-N A D P$ & Net Activity & $\begin{array}{l}\text { G-6-PD } \\
\text { (Gross) }\end{array}$ & $c-N A D P$ & Net Activity \\
\hline $\begin{array}{l}55.7 \\
76.9 \\
67.2 \\
38.0 \\
65.9 \\
59.6 \\
26.5 \\
56.3\end{array}$ & $\begin{array}{r}8.8 \\
23.3 \\
14.9 \\
12 \cdot 4 \\
12 \cdot 3 \\
21 \cdot 1 \\
13.0 \\
20.7\end{array}$ & $\begin{array}{l}46 \cdot 9 \\
53 \cdot 7 \\
52 \cdot 3 \\
25 \cdot 6 \\
53 \cdot 6 \\
38 \cdot 5 \\
13 \cdot 5 \\
35 \cdot 6\end{array}$ & $\begin{array}{r}65.5 \\
97.4 \\
78.3 \\
47.7 \\
115 \cdot 2 \\
122.4 \\
40.5 \\
77.5\end{array}$ & $\begin{array}{l}39 \cdot 6 \\
48 \cdot 8 \\
34 \cdot 1 \\
36 \cdot 3 \\
88 \cdot 8 \\
93 \cdot 1 \\
21 \cdot 0 \\
40 \cdot 0\end{array}$ & $\begin{array}{l}25.9 \\
48.6 \\
44.2 \\
11.4 \\
26.4 \\
29.3 \\
19.5 \\
37.5\end{array}$ \\
\hline
\end{tabular}

Table II Comparison of net enzyme activity (gross less control) after 90 minutes' incubation at $\mathrm{pH} 7.3$ for glucose-6-phosphate dehydrogenase (G-6-PD) in unfixed smeared cells compared with cells incubated in suspension ${ }^{1}$

${ }^{1}$ Each figure represents the mean score, in arbitrary microdensitometer units, for $\mathbf{5 0}$ lymphoblasts. Cell nuclei were counterstained with methyl green which caused some absorption of the transmitted light at $550 \mathrm{~nm}$. The control values (c-NADP) in smeared cells are largely a measure of this rather than of formazan production. great as in the cell suspension technique. Eigft acute leukaemic marrows were processed by both techniques simultaneously for the soluble enzynie glucose-6-phosphate dehydrogenase. Leukaem cells were studied since the blast cell is particularly vulnerable to disruption when marrow or blod films are made. The mean figure for the net activity of this enzyme in smeared cells wo $39.9 \pm 14.6$ compared with $30.3 \pm 12.5$ in cents incubated in suspension. The higher net value $\mathbb{g}_{n}$ the smeared cells is largely due to the lower contiol activity (Table II) but the increase is not statistically significant ( $P>0.5$ derived by Student's $t$ test) due to the individual variation between patients. From these results it would appear that no gross loss of demonstrable intracellular enzyme ocç̄ss when the cells are smeared onto glass slides and Ficoll may act in some way to preserve the labffe binding of the enzyme.

\section{Discussion}

The action of Ficoll in preserving the integrity $\overrightarrow{\mathbb{B}}_{\mathrm{f}}$ mitochondrial and cytoplasmic membranes these experiments appeared to be a non-specific one possessed, at least in part, by other polymere. Solutions of this inert, high molecular weight, synthetic sucrose polymer possess high density, yet low viscosity, and the resulting ease of haniling was a major factor in our choice of this adeittive. Its membrane-stabilizing effect does not block the entry of substrate into mitochondria and therefore does not prevent the cytochemical demonstration of intramitochondrial enzyms (succinate dehydrogenase) but it does prevent the cytochemical demonstration of lysosomal exzymes; reactions for $\beta$-glucuronidase and aryl sulphatase in unfixed marrow films are negat fe when a $40 \%$ concentration of Ficoll is added $\Phi 0$ the incubation medium (Mann, Simpson, Muṇkley, and Stuart, in preparation).

Two techniques are now available for the cytochemical demonstration of dehydrogenase enzyme activity in unfixed leucocytes. Either the cells are spread onto glass slides, air dried, a then immersed in the appropriate incubati $\overline{\bar{\beta}}$ medium, or the chemical reaction is carried ogt beforehand, while the intact cells are suspendeding the incubation medium, and the cells aje subsequently spun directly onto glass slides inoa cytocentrifuge (Stuart et al, 1969). A 40\% cocentration of Ficoll may be used with eitker method. The advantages of the spread film technique include slightly larger and moge easily recognized cells, considerably weaker endogenous control activity, and a more uniforinn enzyme reaction from cell to cell in the same fitw (Fig. 2). These advantages are conferred by the lateral shearing force required to spread the film. Leucocytes cultured in vitro are more read disrupted when smeared onto slides than 


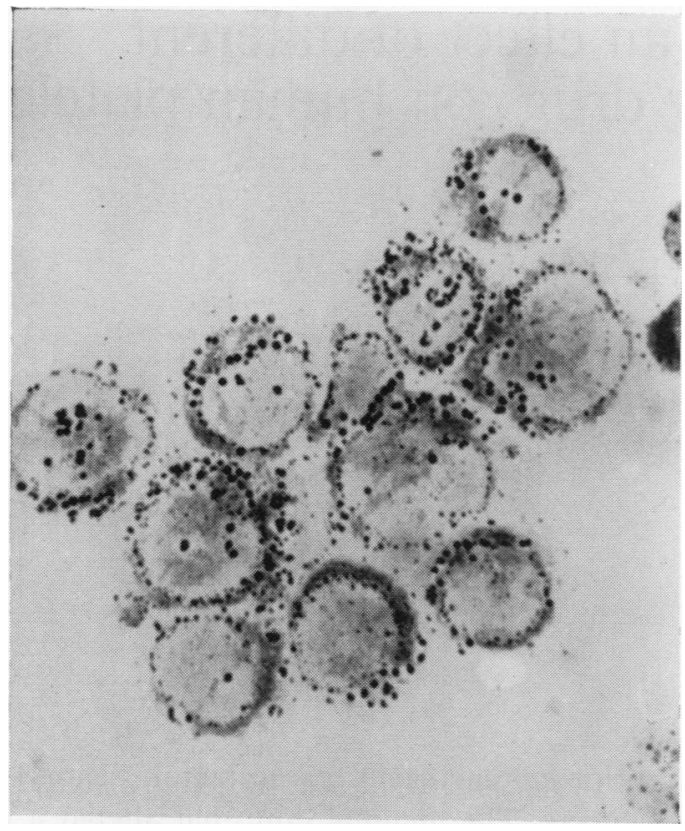

Fig. 3 Malate dehydrogenase activity in a 72-hour culture of phytohaemagglutinin-transformed lymphocytes. Cells spun directly on to glass slides in a cytocentrifuge then incubated in the reaction mixture for 90 minutes. No nuclear counterstain.

marrow or peripheral blood leucocytes, presumably due to loss of a protective coating of protein, and to avoid disruption these cells may instead be spun directly onto the slides in the cytocentrifuge before the rings are applied (Fig. 3).

The use of these techniques, together with an objective estimation of the coloured reaction end- product by means of scanning and integrating microdensitometry (Deeley, 1955; Chayen and 0 Denby, 1968; Stuart et al, 1969), should allow more ambitious studies of enzyme pathway 으․ interrelationships in normal and leukaemic leucocytes.

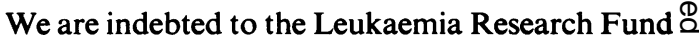
and the United Birmingham Hospitals Endow- ڤ ment Research Fund for financial support, and to $\vec{\circ}$ the following pathologists who made available bone marrow specimens: Dr W. S. A. Allan, Dr I. $\vec{c}$ D. O. Frew, Dr J. G. Hoult, Dr M. J. Meynell, Dr A. Pollock, and Dr R. H. B. Protheroe.

\section{References}

Chayen, J., Bitensky, L., Butcher, R. G., and Poulter, L. W. G (1969). A Guide to Practical Histochemistry. Oliver and Boyd, Edinburgh.

Chayen, J., and Denby, E. F. (1968). Biophysical Technique as Applied to Cell Biology. Methuen, London.

Deeley, E. M. (1955). An integrating microdensitometer for $C$ biological cells. J. sci. Instrum., 32, 263-267.

Lorbacher, P., Yam, L. T., and Mitus, W. J. (1967). Cytochemical demonstration of $\beta$-glucuronidase activity in blood and bone marrow cells. $J$. Histochem. Cytochem. 15, 680-687.

Mann, J. R., Simpson, J. S., Munkley, R. M., and Stuart, J. Lysosomal enzyme activity in acute leukaemia. In preparation.

Melnick, P. J. (1968). Histochemical enzymology of leukemic cells. In Pathology of Leukemia edited, by G. D. Amromin, pp. 125-160. Hoeber, New York.

Quaglino, D., and Hayhoe, F. G. J. (1960). Acetone fixation for the cytochemical demonstration of dehydrogenases in blood and bone marrow cells. Nature (Lond.), 187, 85-86.

Stuart, J., Bitensky, L., and Chayen, J. (1969). Quantitative enzyme cytochemistry of leukaemic cells. J. clin. Path. 22, 563-566.

Stuart, J., and Skowron, P. N. (1968). A cytochemical study of marrow enzymes in megaloblastic anaemia. Brit.J. Haemat., 15, 443-454.
.

Wagner, R., Meyerriecks, N., and Sparaco, R. (1956). Enzyme studies on white blood $\mid$ cells and blood platelets.
Dehydrogenase activity. Arch. Biochem., 61, 278-290. 